\title{
Commentary
}

\section{What Happened to the Women in Women's Studies? Rethinking the Role of Women's History in Gender Studies Classes}

\author{
Lindsey Feitz \\ Gender and Women's Studies Program, University of Denver, Denver, CO 80208, USA; lindsey.feitz@du.edu; \\ Tel.: +1-303-871-2646 \\ Academic Editor: Manisha Desai \\ Received: 1 September 2016; Accepted: 15 December 2016; Published: 18 December 2016
}

\begin{abstract}
This commentary discusses the evolving dynamics and the intergenerational "rifts" that often arise in gender and women's studies classes. The first section outlines the rise of women's studies programs in the 1970s and the "women-centered" approach most university women's studies programs and classes embraced. The second section discusses 3rd wave feminism's expanded interest in intersectionality, masculinity studies, and queer studies and concludes by exploring the possibilities of using the history of women's studies programs as a way to teach students about the shift of "women to gender" studies and to encourage cross-generational dialogue between feminists.
\end{abstract}

Keywords: feminism; women's studies; gender studies; millennial feminism; women's history

Last February while stumping for Hillary Clinton in her bid for the Democratic Party's nomination for President of the United States, former Secretary of State Madeline Albright made headlines when she reminded young female Bernie Sanders' supporters of the importance of supporting a female candidate. The video footage shows Albright saying, "We can tell our story of how we climbed the ladder, and a lot of you younger women think it's done ... It's not done. There's a special place in hell for women who don't help each other!" A week later, second-wave feminist icon and activist Gloria Steinem raised the stakes by implying that young women who supported Bernie Sanders were doing so to meet boys. The response to Steinem and Albright's comments were immediate and angry as millennial feminists took to blogs, internet op-eds, and social media and criticized both Steinem and Albright for assuming that they needed a "talking to" about the importance of electing women to political office or that their support for Sanders stemmed from a desire to please-or find-a man. As the New York Times reported, "In numerous remarks on social media over the weekend, female supporters of Mr. Sanders accused both women of undermining feminism. 'Shame on Gloria Steinem and Madeleine Albright for implying that we as women should be voting for a candidate based solely on gender,' Zoe Trimboli, a 23-year-old from Vermont who supports Mr. Sanders and describes herself as a feminist, wrote on Facebook. 'I can tell you that shaming me and essentially calling me misinformed and stupid is NOT the way to win my vote' [1]."

This example highlights one of the many internal Democratic Party rifts surrounding Hillary Clinton's candidacy for President of the United States, but it also underscores the intergenerational rifts that seem to plague feminists in the United States today. I was not surprised Albright felt compelled to remind young women that Clinton's bid for the highest office in the United States is a profound and ground breaking achievement for all women; nor, however, was I shocked that millennial feminists pushed back by claiming that their desire for social justice encompasses much more than gender equality.

As a Gen-X feminist who teaches “Introduction to Gender and Women's Studies" undergraduate classes these tensions regularly arise in my classes. I cringe when I hear young women, or frankly 
young people in general, dismiss the hard work of the women who paved the way for our access to college, birth control, legal protections, and the myriad of life choices and opportunities that all of us-men, women, and those in between - often take for granted. On the other hand, I have had an equal number of cringe worthy moments in the company of older, usually white feminists, who still assume "woman" is a universal category without accounting for other forms of difference, like ethnicity, class, sexuality, etc.

Second-wave feminists, like Madeline Albright and Gloria Steinem, are often befuddled by millennial feminists calls for them to "check their privilege" and confused when they hear the word "queer" used as a positive affirmation or as a reference to a political group. Add these to discussions about transgender equality, the ongoing battle to secure women equal pay, body autonomy, and at times it feels like we have the makings of a really fantastic intergenerational feminist sitcom where feminists, young and old, speak to each other in different languages. Despite these differences, I don't think we're at a standstill. If anything, these debates highlight how much progress, even if it often is unacknowledged, has been made in women's fight for equality. And yet, my time in the undergraduate classroom repeatedly reminds me that the issues facing women and other minorities today need some academic and historical grounding. In this essay, I would like to take a tentative stab at explaining where these rifts might come from, and more importantly, examine ways that Women's Studies classes (or in my case, Gender and Women's Studies classes) and feminist pedagogy can help provide important and much needed historical, academic, and political context for an evolving field that sometimes feels as though it has left its female founders behind.

Introductory classes are interesting places on college campuses. Regardless of our academic training or field, many of us find ourselves in the unique and often challenging position of being the first person to introduce undergraduates to a field of study or a new mode of critical inquiry. My classes are often the first place students have ever encountered critical gender or feminist studies. Many enroll to fulfill a diversity or common curriculum requirement while others arrive on the first day ready to set the world on fire in the name of feminism.

Despite their divergent backgrounds and reasons for enrolling, most, if not all of my students assume that the Gender and Women's Studies Program on our campus has always existed. I think this "taken for granted-ness" attitude stems from the fact that most of them (including their relatively young-ish professor) grew up in a society that told us that attending college and pursuing our professional dreams was a birthright for all us, regardless of our gender. This of course, doesn't account for the myriad of socio-economic and other barriers that limit access to higher education in our country, but I get the impression that my students don't seem to think gender inequality is one of them. Like me, most of the young women in my classes grew up being told that they too, could be President of the United States, even if they don't feel obligated to vote for a female candidate. I think they also assume that studying women and other minorities' experiences has always been part of a well-rounded university experience.

Thus, the first week of my "Introduction to Gender and Women's Studies" class, I make it a point to tell my students that I hail from a women's studies department that was founded after thirty undergraduate women barricaded themselves in a building at the University of Kansas on 2 February 1972. They refused to come out until the University accepted their demands for an autonomous women's studies department; free daycare; the hiring and promotion of female faculty to administrative positions; targeted recruitment of young women from high school; ending sexist wage policies; and opening a women's health clinic [2]. The February Sisters, as they quickly became known, brought enough provisions inside the building to sustain them for a week. Spurred by a wave of bad publicity and the fear that these unusually angry Midwestern "girls" meant business, university administrators acquiesced to the February Sisters demands within thirty hours. And thus, the Women's Studies Department and the university sexually transmitted diseases (STD) clinic, affordable daycare, a vibrant research program, and a slew of up and coming female professors and administrators at the University of Kansas was born. 
I share my intellectual and professional lineage with my students during the first week of class for a number of reasons. Part of it stems from pride, but I also think it is important for students to recognize that women's studies (and other academic programs aimed at expanding minorities' access to higher education) did not fall out of the sky. The February Sisters at the University of Kansas did not act out of isolation; most Women's Studies Programs were born out of student, faculty, and community protest. The university system in the United States and higher education in general, was not built by or for women or people of color, a fact that many of us realize once we find ourselves inside of it. As much as I have always loved and admired Horace Mann, his famous call for education to be the "great equalizer" in the United States was aimed at providing educational and vocational opportunities for young white men in the early days of the Republic and his vision for women stopped at teacher-education training.

In my classes, it becomes apparent early on that very few of my students realize this or the degree to which women and other minorities were excluded (and still, unfortunately, sometimes are) from the hallowed halls of higher education and that the very existence of women's studies programs, along with our allies in Black/Chicana/Native and other ethnic studies programs are indebted to student activists who were inspired by the Women's Liberation, Civil Rights, and Gay/Lesbian liberation, and Anti-War movements of the late 1960s and 1970s. Before then, women and minority students had to fight tooth and nail to get into universities in the first place, and once there, found themselves reading textbooks where their life experiences were either invisible or relegated to a footnote. This slight was often compounded when students found themselves listening to lectures given by professors whose life experience looked very little like their own.

Clearly, these are still pressing problems today on college campuses. And yet, I think it is worth noting that before the late 1960s, the de facto segregation that denied students of color equal access to higher education paralleled many of the challenges female students faced, especially those who attended public universities. Young women who were encouraged to pursue a public education outside of high school or vocational training often faced limited choices (e.g., nursing, teaching, or secretarial work) and were often banned from programs like business schools that would open doors to challenging careers where, in theory, they could be financially independent. Young women often found themselves seeking out the few female faculty members on their campuses as mentors or taking a patchwork of classes in art history, anthropology or literature that lent insight into women's or gender related issues. As Stephanie Evans points out in her book Black Women in the Ivory Tower 1850-1954: An Intellectual History, young women of color faced and surmounted extraordinary barriers in gaining access to a formal education at universities before the 1960s [3].

This lack of understanding is also compounded by the fact that most of my students know very little about U.S. Women's history. During the first week, I remind my students that before 1974 single women in the United States were unable to get credit without a male cosigner and had faced significantly higher interest rates. Before that, women had few legal protections or support if they wanted to leave abusive husbands or unhappy marriages. Marital rape wasn't criminalized in all fifty states until 1993. For women who worked outside their homes before the 1970s, they had few, if any, legal statutes to protect them from losing their job due to pregnancy or sexual harassment. The Equal Pay Act did not become law until 1963 and unfortunately did little to help women, many of whom were women of color, who were relegated to working in informal environments (including in other women's homes) and who faced even fewer options for upward mobility. Considering that throughout U.S. history, and especially during the Cold War, women were expected to marry young and raise a family, it is a wonder that they found the time or energy to pursue their dreams of higher education. Second wave feminists like Betty Friedan helped launch second wave feminism and the Women's Liberation Movement, both of which were marked by public activism aimed at combatting sexism and giving women the opportunity to live equal, independent and free lives.

When put into context, it makes sense why second wave feminists believed that young women not only had a right to higher education but that universities also had an obligation to create spaces where 
women could study their own experiences (the personal is political, after all), as well as supporting research dedicated to unraveling the long and thorny history of patriarchy. In 1970, San Diego State became the first university to house an official Women Studies Department and by 1977 the National Women's Studies Association was created. By the mid-1980s, the NWSA estimates that approximately 276 women's studies programs existed on college universities across the United States [4].

Many women's studies programs in the 1970s offered classes where "common-sense," (i.e., male-centered) ways of knowing and understanding the world would be questioned and critical inquiry would produce new forms knowledge. Not surprisingly, many early women's studies faculty members' pedagogy and course offerings were inspired by their feminist activism in the 1970s, and more often than not, classes and programs were dedicated primarily to studying women's oppression and lived experiences.

As many feminists correctly pointed out, while well intentioned, many of these classes were taught by white women and spoke to white women's experiences. Discussions of working women, lesbians, and women of color often took a backseat to white, upper-middle class women's experiences and as bell hooks notes in her book Feminism is For Everyone, many women engaged in feminist activism and teaching outside the academy were seen as unqualified instructors once women's studies became institutionalized [5]. On the reverse end of the spectrum, newly developed women's studies departments also faced ongoing criticism from people who believed that putting women's experiences at the center of study amounted to reverse discrimination against men. Often seen as the poster child of "man hating" women's studies professors, Mary Daly, a radical feminist professor at Boston College, famously refused to allow males into her advanced women's studies classes during the 1970s until 1999, when she was forced to resign after refusing to change her policy at the University's request [6].

Daly's forced retirement ironically coincided with rumblings by a new generation of "third wave" feminists, a term coined by Rebecca Walker, daughter of renowned African American novelist Alice Walker. Walker called for a shift in feminist activism and study that would encompass the multitude of young women's experiences [7]. Young women of the 1990s, including some who majored in Women's Studies at universities across the United States, found themselves living in world where questions about race, globalization, new technology and masculinity started to permeate discussions about feminism on and off campus. Scholarship in fields ranging from sociology and new media studies began asking questions about the importance of gender constructions (and constrictions!) for all people, including men and transgender folks. Feminists of color increasingly called out white feminists in the academy for our long history of speaking on behalf and for them. Young women were encouraged by popular culture and sex-positive feminists to embrace their sexuality and their "girly side", a move that flew in the face of second wave feminism but coincided with a new burgeoning field of queer studies that challenged heteronormative understandings of human sexuality.

These criticisms played out on university campuses and in women's studies programs where faculty negotiated how to address changing times. The NWSA's 2007 "National Census of Women's and Gender Studies Programs in U.S. Institutions of Higher Education" notes that Women's Studies Departments and Programs founded in the 1970s and 1980s began to reevaluate their approach to teaching and researching women's oppression. Many elected to add "Gender" and "Sexuality" to their institutional titles and now serve as umbrella sites where students engage in intersectional critiques of gender alongside investigations of race, sexuality, class, nation, ability, religion, and other factors that shape systems of oppression and people's experiences. In 2007, the NWSA estimated approximately 650 Women's AND/OR gender studies departments and programs exist throughout the United States [5].

The shift from "women" to "gender" studies in higher education mirrors the shift from "second" to "third" wave feminism that challenged feminists to reevaluate how inequality and patriarchy function. Neither are inherently stable or monolith, and third wave feminists' call for intersectional analysis has not only created a more inclusive view of feminism, but one that is also smarter and accounts for the common sense, inevitable differences that women and men experience as they move 
through this world. I tend to think that the shift from "Women" to "Gender/Sexuality/Queer" studies on college campuses has had a similar effect because it gives students the opportunity study gender inequality from a variety of perspectives and accounts for the important ways other facets of identity and power operate.

However, I don't know if this institutional and theoretical shift from "women" to "gender" has permeated discussions of feminism and women's equality in the public sphere, as evidenced by the defensive game Albright and Steinem found themselves playing after their comments last spring. If these conversations are happening, they seem to be limited to the blogosphere or on clickable websites like Upworthy where young feminists (including men and gender queer folks) are more likely to turn for updates on feminist issues [8-10].

There's no doubt that the internet and social media have helped fuel a new and exciting awareness about feminism. But, as an educator and a professor with a deep affinity and appreciation for Gender and Women's Studies, the lack of historical context in these conversations is frustrating. However, I have increasingly found inspiration in my college classroom, where I have the opportunity to bridge these institutional and generational divides with students from a range of backgrounds. Some, as I mentioned earlier, simply want to fulfill their common curriculum requirement, but in the last several years, new batches of students arrive on the first day proclaiming their interest in queer studies, transgender equality, critical race studies, or masculinities.

Several of my students have already self-identified themselves as "fourth wavers" whose interest in feminism has less to do with women's inequality and more to do with the discrimination transgender and genderqueer folk's experience. Others talk about their interest in how gender operates in social movements like Black Lives Matter, immigration reform, or climate change. It is exciting to hear their take on where feminism is headed and their desire to refashion it for the challenges facing our world today. My job, as I see it, is to help hone their critical thinking skills and to teach them how to use gender and other categories of identities as tools for analysis with the hopes that they will better understand, and maybe even help solve the myriad of problems that plague our world.

But, what my classes are missing, or at least need more of, is the opportunity to hear from women like Madeline Albright or the February Sisters who were on the front lines battling for the right of future generations of women to have the opportunity to both attend-and transform-institutions of higher learning and the world that awaits them after college. In a perfect classroom, I would love to add an "old school" second wave feminist to my mix of students. I have a feeling she could teach my male and female business students about sexism in the workplace and add an important perspective to my "fourth-wavers" understanding of gender fluidity. (I have a feeling she might think sexism and gender fluidity might be at odds with each other in ways that we are still working through as scholars ... ). I have no doubt it would probably lead to heated discussions about racism and classism that plagued many second wave feminist circles; but I also can't help but think it would provide young students like Zoe an opportunity to understand where women like Madeline Albright and Gloria Steinem are coming from and why they seem so irritated that young people have forgotten that "women"—as a singular, yet diverse category—are still worth supporting and fighting for.

Then again, I can't help but think that older feminists, especially white women, would benefit from hearing about young people's concerns, and why many of them see feminism as much more complex than women's universal fight for equality. As much as I sometimes tire of hearing students telling each other to "check their privilege", its evidence of smart, intersectional thinking that older feminists might find useful in explaining and thinking through some of the internal rifts that divided some Women's Liberation activists.

By their nature, introductory classes are limited in terms of what we can feasibly teach students. But providing historical context about the battle to establish women's studies departments is an important and much needed history lesson that can help students understand the evolution from "women" to "gender" studies, and maybe even foster a more productive cross-generational dialogue outside the classroom. There's something special about an introductory classroom that mirrors the 
dynamics of the "real world" and as feminism outside the academy continues to evolve, I'm beginning to realize, so must my pedagogy. For me, this means taking more time to revisit women's history as we move towards a future fraught with challenges that in many ways mirror those that the women before us experienced.

Using the singular category of "woman" as the cornerstone for academic studies has gone by the wayside for many of us who teach gender studies and I worry that we may have forgotten, or maybe never realized, the importance of women's history. Feminists have a long history of sharing, supporting, and combatting sexism outside the hallowed halls of higher education, but it is important to remember that women's studies departments have never had it easy, nor have our allies in ethnic studies or other programs that help students and faculty fight to transform the ivory tower. By incorporating these histories into our classes, I can't help but think that our students, as well as our universities, might be reminded of the importance and necessity of making higher education the great equalizer for all of us.

Conflicts of Interest: The author declares no conflict of interest.

\section{References}

1. Rappepart, Alan. "Gloria Steinem and Madeleine Albright Rebuke Young Women Backing Berne Sanders." The New York Times, 7 February 2016. Available online: http://www.nytimes.com/2016/02/08/us/ politics/gloria-steinem-madeleine-albright-hillary-clinton-bernie-sanders.html?emc=eta1\&_r=0 (accessed on 19 August 2016).

2. KU History: The University of Kansas. "Sisters Act: 4 February 1972." Available online: http://kuhistory. com/articles/sisters-act/ (accessed on 25 August 2016).

3. Evans, Stephanie. Black Women in the Ivory Tower, 1850-1954: An Intellectual History. Gainesville: University of Florida Press, 2008.

4. Reynolds, Michael, Shobha Shagle, Lekha Venkataraman, and National Opinion Research Center. "A National Census of Women's and Gender Studies Programs in U.S. Institutions of Higher Education National Association for Women's Studies Report." National Association of Women's Studies, 26 December 2007. Available online: http:/ /www.nwsa.org/files/NWSA_CensusonWSProgs.pdf (accessed on 30 November 2016).

5. Hooks, Bell. Feminism Is for Everybody. Cambridge: South End Press, 2000, pp. 7-12.

6. Boston College: BC News. "Mary Daly Ends Suit, Agrees to Retire." Available online: http://www.bc.edu/ bc_org/rvp/pubaf/chronicle/v9/f15/daly.html (accessed on 21 August 2016).

7. Walker, Rebecca. "Becoming the Third Wave." MS Magazine. Available online: http://www.bc.edu/bc_org/ rvp/pubaf/chronicle/v9/f15/daly.html (accessed on 30 August 2016).

8. "Upworthy." Available online: http://www.upworthy.com/ (accessed on 30 November 2016).

9. “Everyday Feminism." Available online: http:/ / everydayfeminism.com/ (accessed on 30 November 2016).

10. "Jezebel." Available online: http://jezebel.com/ (accessed on 16 December 2016). 